\title{
Appendix B: Bolingbroke’s army in 1399
}

The following list of those who received wages for accompanying Bolingbroke on his march through England in the summer of 1399 is compiled principal ly from a Duchy of Lancaster account in the Public Record Office (DL.42/ 15, ff. 70-71), with some additional information taken from another Duchy account (DL.28/4/ 1, f. 19), and from the exchequer issue roll (E403/564, various dates). Almost all of those listed below were paid not only for 'coming to the king (Henry) after his arrival in England,' but also for 'remaining with him during the parliament at Westminster.' The list bears out the comment of the Dieulacres chronider that 'numerous noble and warlike men from the north and from Lancaster, Derby and Stafford gathered with him (Henry)' (Dieulacres Chronicle, 171). In those cases where the ministers responsible for making payments are specified, they are mostly from the great northern and north midland honours of the Duchy of Lancaster, such as T utbury, Pontefract, Lancaster, Bolingbroke and High Peak. I ndeed, comparison of York's and Bolingbroke's armies suggests a significant element of division al ong regional lines in 1399, though this could have been due to the circumstances of the moment as much as to deep-rooted pol itical affiliations. Morethan half of those listed bel ow had also been retainers of J ohn of Gaunt. Unfortunately the number of soldiers accompanying the recipient is never specified, though the total sum paid out - approximate y $f 4,900$ - was certainly large

\begin{tabular}{lrl}
\hline Commander & Wages $(£)$ & Paid by receiver of \\
\hline Earl of Northumberland & 1,333 & \\
Sir Henry Percy & 666 & \\
William Lord Willoughby & 623 & \\
Robert Waterton, esquire & 285 & Pontefract \\
Sir Walter Blount & 233 & Tutbury \\
William Lord Roos & 200 & \\
Sir Thomas Wendesley & 160 & High Peak \\
Earl of Westmorland & 146 & \\
J ohn Curson, esquire & 100 & Tutbury
\end{tabular}


Sir Thomas Gerard

Sir T homas Beck

Sir J ohn Cokayn

Sir Roger Swillington

Sir Nicholas Montgomery

Sir J ohn Dabrichecourt

Sir Robert Rokely and William Drummond

Thomas Gresley, esquire

Sir Gerard Usfleet

Sir Thomas Hercy

Sir Nicholas Langford

Sir John Berkeley

Sir William Dasteley

Sir Thomas Aston

Thurstan de Boure, esquire

Thomas Foljambe, esquire

Sir Richard Stanhope

Thomas Clavel, esquire

Sir Robert Nevill

J ohn Langford

Sir Hugh Shirley

Thomas Mereward

Roger Bradbourn, esquire

Bartholomew M ontgomery, esquire

Henry Vanes, esquire

Richard Gascoigne, esquire

Simkin Franceys, esquire

Sir Hugh Husee

Henry Bothe, esquire

Edmund Barry, esquire

John Leventhorpe, esquire

William Kettering

John Reynes, esquire

John Ayresworth, esquire

Ralph Burburgh, esquire

J ohn de Normanton

Henry Bradfiedd, valet

Aultyn Houby

Thomas Cokfeld, esquire
93

86

66

66

66

60

51

50

40

40

40

33

33

33

30

30

30

26

20

20

20

18

17

16

14

13

12

12

12

10

10

10

10

8

8

7

6

6

5
Lancaster

Tutbury

Tutbury

Pontefract

Tutbury

Lancaster

Tutbury

Ponterract

Bolingbroke

Lancaster

T utbury

High Peak

High Peak

Bolingbroke

Ponterract

Pontefract

Leicester

High Peak

Lancaster

Bolingbroke

Knaresburgh

Tutbury

Bolingbroke

Tutbury

Norfolk

Hertford

Pontefract

Norfolk

Lancaster

Tutbury

Tutbury

Leicester

Tutbury 